Миодраг Јовановић

Универзитет у Црној Гори

Филолошки факултет

Никшић
821.163.41:929 Караџић В. С. https://doi.org/10.18485/ai_lik.2018.4.5.5

\title{
АЛЕКСАНДАР БЕЛИЋ О ВУКОВИМ ПОГЛЕДИМА НА ЈЕЗИК КЬИЖЕВНИКА СВОГА ВРЕМЕНА КАО ПУТОКАЗУ СТВАРАњА „БЕОГРАДСКОГ КРУГА“
}

Александар Белић био је велики поштовалац Вукове личности и Вуковог рад - чак је о томе писао, најчешће с великим одушевљењем. На темељу Вукових реформи, у Београду крајем XIX и на почетку XX века, почео се појављивати посебан поетски израз, онај који би све чешће био познат као „београдски стил“, или се чак сматрао првим књижевним језиком у Србији. Поред рођених Београђана, „београдски стил“ формирали су и књижевници са стране, који су у главни град долазили често и из врло удаљених крајева и ту остајали да живе и раде. У овом раду покушаћемо да дођемо до одговора на питања шта он значи за наш књижевни језик и шта он ново у њега уноси; откад постоји „београдски стил“, како је настао и које су његове основне особине.

Кључне речи: Александар Белић, „београдски стил“, Вук Караџић, језик.

Давање потпуне слободе народним говорима у књижевности у почетку свога рада произашло је из чињенице да Вук тада није знао за велике разлике међу нашим дијалектима. Он је мислио да јединство књижевног језика долази природно из особина дијалеката који су у великој мјери међусобно блиски. На том ће принципу, сматра Белић, Вук остати и због неких других разлога: „од предлагања једног дијалекта као књижевног могао га је, донекле, одвраћати и Копитар, јер он није био присталица наметања једног месног говора целом народу, а у исто време није губио из вида и корист коју 
наука о српском језику може имати од напоредног изношења у књижевности различних дијалеката; и, најзад, од тога да свима Србима предложи један, нпр. херцеговачки говор, задржавала га је и жучна опозиција на коју је наишао његов херцеговачки говор код војвођанских Срба“. Пријатељство и сарадња (30 година) двојице сељачких синова, Словенца Јернеја Копитара и Србина Вука Стефановића Караџића, довели су до успјешног спровођења реформи, побједе народног језика и почетка стварања модерне књижевности.

Значајна путовања по јужним и југозападним крајевима наших народа (1834-1839), увјериле су Вука да су разлике међу говорима много више и дубље, од оних које је изнио у ранијим подјелама, па би се до јединства књижевног језика могло доћи једино ако би се један дијалекат узео за књижевни. Под утицајем таквих тежњи, у полемици са Милошем Светићем под насловом „Одговор на ситнице језикословне г. J. Хаџића = М. Светића“, засновао је и изнио трећу дијалекатску подјелу (1839. године) на источни, западни и јужни говор, која се сматра темељом књижевног језика. Доминантна разлика међу њима био је изговор старога вокала јат (друге разлике Вук је занемарио) тако да су сви ови говори могли имати значајан удио у непосредном стварању књижевног језика - а то је велики простор бивше државе: велики дио Србије (Шумадија и цијела сјеверозападна и југозападна Србија), Црна Гора, Босна и Херцеговина, Славонија, Хрватска јужно од Купе, Далмација и Војводина. Знао је Вук, наглашава Белић, да би друге разлике међу њима, „које су му знатним делом биле познате, унесене у књижевни језик, учиниле немогућим јединство књижевног језика и унеле би велику самовољу у бележење различитих облика какве нема у другим књижевностима“. Требало је, знао је и чинио Вук од 1814. до 1864. године, у народном духу и од чисто народних елемената створити нову зграду српског књижевног језика. А то је језик који се „у свима појединостима, онакав какав је, нигде не говори у народу, макар да опет у њему нема ниједне појединости која се негде у народу не би говорила“. Требало је, из већ обимне грађе народних говора, коју је сакупио на терену, оцртати особине које ће бити узор будућег народног књижевног 
језика јер се у њему „нису смеле находити хаотично измешане црте свих народних говора“ - зато је Вук „одредио и тешку и лепу дужност књижевницима свога народа: да од народних црта проберу оне које су за књижевност“. Тако је овај реформатор, што би рекао велики познавалац и поштовалац рада Вука Стефановића Караџића Александар Белић - „полазећи од народног језика у књижевности нашега народа и народне књижевности оличене у народним песмама и приповеткама постепено прилазио проучавању и других народних особина, и тако нам давао грађу за леп српски језик“.

Пишући (и скупљајући) народне пјесме, због чега су, како сам Вук каже, његови противници са њим „спрдњу тјерали“, он је увидио да постоји огромна разлика између језика којим говори прости народ и славеносербског језика, којим се пишу књиге, школски уџбеници и којим се служи администрација. Народне пјесме, приче и пословице свједочиле су да се живим језиком којим народ говори могу изражавати дубоке мисли и сложена осјећања. Родила се већ тада мисао да застарели и мртви црквени језик у школи и књижевности треба замијенити правим народним језиком. Зато је савјетовао (или наређивао) књижевницима да не пишу језиком који су учили у школама, заснованом на народу страним (њемачким, латинским и црквенословенским) основама, да се врате у народ да од њега уче и поправе свој језик, или и од Вука лично и његових дјела. Јасно је, књижевници то нијесу хтјели прихватити јер је „против природе и против сваког здравог разума да учени људи иду некоме у школу, да они који треба народ да просвећују иду народу да се од њега просвете“. „Пишите или правилним црквенословенским језиком, па нека вас читају који тај језик разумеју, али кад хоћете народу да говорите, морате му писати чистим народним језиком, и то оним начином да он тај језик разуме. Без тога нисте народни књижевници, нисте књижевници уопште и ником нисте потребни; још, напротив, тада сте само штетни“ - мислио је и говорио Вук. Свако одступање од чистог и правог народног језика он је осјећао као нарушавање светиње.

Борба за народни језик створила је Вуку велики број моћних противника за које је он био „сербског језика 
помрачител“, нико од Косова до тада није нанио толико штете и срамоте српском народу као он - говорили су му у лице. За Вуков тадашњи рад могло би се са доста оправдања поновити оно што је Мушицки (у прво вријеме пријатељ и одушевљени сарадник Вуков) рекао некад за Вуков Рјечник: „публична и јавна хула, гнушеније, презреније и омерзјеније“ - његови су пратиоци.

Вуков захтјев за нераскидивом везом књижевника с народом, с милионима људи који говоре српским језиком, сматрао је преимућством Вука над противницима, и као сигуран пут до коначне побједе, још један велики поштовалац дјела овог реформатора - Иво Андрић. За њега је Вук творац чисте српске прозе и стила, отац српске књижевности, а Вукову идеју да „матерњи језик треба онако писати као што га милиони душа говоре“ сматрао је логичном и визионарском. Признао је једном приликом овај нобеловац да је њему од лингвистичке литературе прво и најчешће при руци био Вуков Рјечник и да се, при стварању својих дјела и разрешавању језичких дилема, са увјерењем држао тамо нађеног мишљења.

Првобитни принцип „пиши као што говориш“ Вук је доста брзо замијенио принципом „опћене правилности“ то су оне језичке црте које су у свима књижевним (и сродним) дијалектима једнаке (највећим дијелом припадају јужном нарјечју, али знатним дијелом и источном, па и једном дијелу западних говора), а препознатљиво се разликују само постојаношћу употребе једног замјеника старога вокала јата. Вук је сада могао рећи и оно што је тако дуго тајио, како и сам вели, којим би дијалектом ваљало сви Срби да пишу, а то је његов завичајни херцеговачки говор. Заправо, Вук је још почетком 1822. године ту идеју открио у писму Мушицкоме: „Ерцеговачким нарјечијем ја сам почео писати, али нијесам казао још никоме (нити сад мислим) да је Сремачко и Бачванско нарјечије ружније од Ерцеговачкога. Ја нити пишем за Сријемце, ни за Бачване, ни за Ерцеговце, ни за Црногорце, него за све Србе“. Ипак, већ тада је волио помало да истиче херцеговачко нарјечје: „У народним нашим пјесмама, које су једино и вјечно благо и украшеније литературе наше, пјева се и данашњи дан усред Бачке и Сријема, као и усред Браничева 
и Ресаве, бијело, лијепо“. А тај књижевни језик Вуков, већ у његово вријеме, почео се одвајати од народног језика и оних крајева из којих је поникао - изнад свега, пошло се за поштовањем правила „опћене правилности“.

Нијесу баш сви писци и научници били против Вуковог рада - њему је пуно значила подршка коју су у том правцу, додуше у каснијој фази реформе, дали Ђура Даничић и Бранко Радичевић. Даничић је својим радовима, истицао је Белић, „избијао из руку Вукових противника оно оружје које је било у оптужби Вукова језика у несавршености и неподобности да се њиме обрађују научне теме“. Насупрот, он је доказао да књижевном језику заснованом на народној основици не недостаје „ни јасност, ни убједљивост, ни научна терминологија, ни кристална чистоћа језика“. Исте године кад и Рат за српски језик и правопис и Вуков превод Новог завјета потврдио је „гипкост Вукова језика“ којом је између осталог показао како треба градити нове ријечи или их узимати из других словенских језика, кад књижевницима затребају. Не само што је у одбрану језика српскога Даничић стао научно, већ није крио ни личну емоцију, када је писао - „Народне су умотворине сјеме: из тога сјемена треба да нам никне књижевност; то ће само бити права књижевност. Вук нам је тијем сјеменом њиву посијао“. Уз то, идући за Вуком, у писаном изразу је стално употребљавао јужно нарјечје (само је једну годину, између 1857. и 1858, писао источним нарјечјем, које је за војвођанске књижевнике била једина варијанта). Пјесник Бранко Радичевић показивао је својом распјеваношћу на народном језику колике су његове могућности за стварање књижевних дјела. Вуков језик је у реализацији пјесничких идеја непресушан извор, зато „треба писати онако како народ говори, треба се вратити себи, језику очева и мајки који нијесу учили школе и нијесу свој језик искварили“.

Сав рад Вука Стефановића Караџића пропратио је научним пером, бавећи се пола вијека његовим дјелом (најчешће с одушевљењем), знаменити лингвиста Александар Белић. Ево, на примјер, што је у таквом тону о њему писао: „Велика фигура Вукова, сва од једне стене, непомична и поносито уздигнута, на оној великој висини на коју се Вук успео у 
почетку свога рада и која ће допустити да га поколења нашег народа вековима сагледају са поштовањем и дивљењем“. ... Све клевете, сви злобни напади, све животне незгоде нису могле свући Вука са те висине ни за један корак: целих педесет година стајао је он на мегдану свима и свакоме док није извојевао своју победу, победу која је ишла само народном добру и народној срећи. „Војвођанска црквена управа, која је у својим рукама држала целу просветну политику Срема, Бачке и Баната, и државна управа у Србији, опет под утицајем црквених управљача у Србији, све до краја педесетих година (до приближно1860. г.), - биле су отворени противници Вукови. ... А Вук је стајао на својој гранитној стени доказујући да су његови нападачи безумници који не знају шта говоре и на шта се каменом бацају“.

Који дјелови наше земље или нашег народа могу бити по природи својој понајприје творачки у природном развитку књижевног језика? Да ли у томе учествује и београдско грађанско становништво и књижевници или се у том крилу траже нови путеви његовом развоју и да ли се одређени процеси, који се обично називају „београдским стилом“, а који се препознају и постепено шире крајем 19. и почетком 20. вијека, одвијају у духу Вукова језика такође су често били научна преокупација Белићева. Тражио је у вези са тим одговоре на бројна питања: Како је дошло до посебног „стила“ који се назива „београдским“, при чему синтагму „београдски стил“ увијек ставља под наводнике, или употријеби одредницу такозвани. Шта он значи за наш књижевни језик и шта он ново у њега уноси; откад постоји „београдски стил“, како је настао и које су његове основне особине, да ли се између књижевника „београдског стил““ и самога Вука може поставити граница? - на та питања у нашем раду могу се дати само одговори општије природе. Са које стране уопште прићи овим питањима, такође је била наша дилема. У једном тексту у дневном листу Данас од 17. јануара 2014. године од аутора Софије Живковић, под насловом „Београд се не завршава никад“ прочитали смо да је „београдски језик“ први прави књижевни језик у Србији. И то се мишљење све више чује, но да ли је засновано на научним чињеницама, 
одговорићемо ријечима самога Белића. Да постоји указивао је својим ауторитетом Јован Скерлић још 1907. године кад указује на то да су се „духовни видици проширили, душе су постале сложеније, и за нове идеје и за нова осећања ствара се нови, развијенији, виши књижевни језик“.

Ништа није необично да престолница временом постане државни, национални и културни центар једног или више народа и једне земље и да њен језик буде узор то је постао Београд. Комуницирајући непосредно са великим центрима свијета и посредно (књигом - васпитавајући се и продубљујући своје погледе и осјећања на сјајним дјелима свјетске цивилизације) Београд и београдско грађанско друштво почели су се изграђивати у духу европских вриједности. Људи који су радили на књизи и уопште у култури устаљивали су особен израз - „јединство места и јединство живота учинило је да сви они који дуже времена у Београду станују, који се у њему рађају и у њему живе, радећи и на књижевности или науци његовој, - почињу да пишу или говоре, иако не потпуно истоветним, свакако врло уједначеним језиком. Тај уједначени језик интелектуалних кругова београдских и представља београдски књижевни језик“. Реализован у дјелима писаца добијао је препознатљиве обрисе, особине због којих је у савременом добу све више називан „београдским стилом“. Такав начин настајања књижевног језика на одређеном подручју, на којем су се стекли услови за живот неког језика, када се помијеша са стварним животом, препознавао је професор Женевског универзитета Шарл Бали: „Језик је жив само онда када је 'пропуштен кроз осјећање', а он може бити 'пропуштен кроз осјећање', ако је 'проживљен'. Без тога, и најскорашњији је језик само мртав језик“. „Ту слободу стварања, у границама народног духа, која се огледала у живости, живописности, гипкости и снази књижевног језика добрих београдских писаца - и схватали су многи као 'београдски стил'. Међутим то је само показивало колико је правога живота било у том језику“ - говорио је Белић.

Историјски гледано у старој Грчкој још више је него Београд код нас то била Атина, чији се атички књижевни језик, прослављен великим писцима - трагичарима, 
комедиографима, реторичарима - проширио на цијелу земљу и постао једини говорни језик њеног становништва, а главни град, без значајнијег ривалитета, духовна водиља грчког народа. Говорни и књижевни језик престижног париског Ил - де Франса проширио се по цијелој Француској и у крајеве у којима се до тада говорило неразумљивим дијалектима. Додуше, наш народ је доскора имао два културна центра (Београд и Загреб) од којих сваки има своје духовно подручје, иако је и један и други центар прихватио Вуков књижевни језик као основицу свога књижевног развитка. Одлуком илираца да приме јужно нарјечје за књижевно Вук је могао с успјехом ићи ка још једном зацртаном циљу: могао је преко језика извршити јединство српског и хрватског народа - „са браћом нашом Римскога закона који с радошћу нама руке пружају“. Чак је у полемичким окршајима опомињао Србе „да ће ићи у Загреб да уче српски ако Загрепчани продуже радити онако како су почели, а Срби буду занемаривали и даље свој језик као дотле“. Вуково писање правила за јужно нарјечје водило је стварању заједничког књижевног језика Срба и Хрвата.

А препознатљив облик београдском књижевном језику, давале му творачку снагу и прерађивале материјал, почео је да се ствара од првих генерација писаца рођених у Београду и које су кроз београдски живот активно пролазиле. „Тако је после Јована Илића, Београђанина, који је радио за време увођења народног језика у књижевност - указује нам на пут његовог настанка Александар Белић - дошао његов син Војислав и друга браћа његова који већ стварају типични београдски језик. После Милићевића, Шумадинца, његова зета Мите Ракића, Рудничанина, - Милан Ракић је сав Београђанин“. Често се помињу и имена значајних стилиста - Београђана, као што су Богдан Поповић, Јован Скерлић, Љубомир Недић, Слободан Јовановић и многи други (писци, књижевни критичари, научници, публицисти). Треба додати, у обликовању београдског књижевног језика с краја 19. и почетка 20. вијека, у стварању живе, увијек покретне и нове језичке материје, учествовало је подједнако и београдско грађанско становништво.

Поред рођених Београђана, „београдски стил“ формирали су и књижевници са стране, који су у главни град 
долазили често и из врло удаљених крајева и ту остајали да живе и раде. А неки су оставили неизбрисив траг - и у књижевности и у језику: Шибенчанин Симо Матавуљ, Дубровчанин Матија Бан, Јосиф Панчић из хрватског Приморја, Љубомир Ненадовић, Јован Дучић, Иво Андрић, Мита Ракић, Милован Глишић и многи други, који иако нијесу рођени у Београду и они су „добијајући од Београда општи колорит, брзо постајали учесници, каткада снажни, други пут врло танани и гипки, у изграђивању истога ткива књижевнога језика“. Дакле, њихов се књижевни језик брзо и лако спаја са београдским. Не само то, знаменити писци, досељавајући се у овај град, доносили су и особине својих завичајних говора, а понека од тих црта могла се задржати у београдском говору, тј. они су уносили у општу творницу београдског језика нове елементе. Тако је Љубомир Ненадовић донио у Београд свој лијепи говор Бранковине, Лаза Лазаревић - шабачки или поцерски говор, исто онако као што је Јован Дучић, много касније, задио у београдско рухо своју херцеговачку говорну садржину. Ипак, све те говоре београдски језик доста брзо је прерађивао у своме правцу и своме духу. Како Белић каже: „Београд је већ био почео својим великим ваљком да уравњава и ствара стазе по којима се могло лако и удобно ићи“. Могло би се рећи да су ови говори, које је овај лингвиста називао „побеограђени“, утицали на стварање београдског говора, „исто онолико колико им је он давао своју боју, тако да се граница између њих најзад губила“.

Тај новостворени београдски књижевни језик разликовао се од београдског народног говора - заправо, они су се напоредо развијали и преплитали. Јасно је, народни језик према књижевном и у београдској средини стоји исто онако „као што, нпр. језик Мостара стоји према језику Алексе Шантића, или језик Змијања или Бања Луке према језику Петра Кочића“ - каже Белић. И тако га треба схватити.

Међутим, путеви развитка различитих стилова београдских писаца и уопште грађанског становништва сагласни су са основним принципима Вуковог књижевног језика. А његова основица није само београдско подручје, већ и Шумадија, западна Србија и Војводина - рекли бисмо, и Вукова постојбина и постојбина његових противника. Све 
је као код Вука, па ипак је све друкчије. Али то „друкчије“ не иде на штету љепоте и правилности нашег општег књижевног језика, него се креће ка новим висинама и љепотама, које су се већ у заметку криле у Вукову књижевном језику.

Потпуно је природно што књижевници који су се родили у Београду, па и они који ту проведу одређено вријеме, добијају неко заједничко стилско обиљежје различито од других културних центара - јер Београд је релативно брзо, како смо већ рекли, мирио све разлике и стварао могућности за развој београдског језика препознатљивог по слободи стварања. Међутим, то још није „београдски стил“. Каква је, на примјер, разлика, пита се Белић, између стила Јована Скерлића или Слободана Јовановића! „У првога велики ритам који је одговарао стихиској природи Скерлићевој, са искреним, проживљеним реторством које давно избледелим сликама даје нову живост и истинитост, а у другога - простота и непосредност, које наговештавају мислиоца који је много читао и изграђивао себе, - али који још увек тражи да оживи свој стил позајмицама из свакидашњег језика, многобројним инверзијама, елипсама и сличним стилским средствима“. Код Ракића кључају страсти које пјесник ипак успијева да смјести у сажету реченицу. Војислав Илић има свој стил којему су многи сљедовали, али је његов стил друкчији него Ракићев, иако су обојица Београђани и пишу одличним београдским језиком. Тако је Љубомир Недић имао друкчији стил неголи Светислав Вуловић и цијело његово покољење. Идући тим путем код сваког би се београдског књижевника пажљивом анализом могле утврдити извјесне особине стила различите од стила других београдских писаца. Поборници постојања посебног “београдског стила”, препознају, што смо прочитали у Данасу, да је "Симо Матавуљ у Београдским причама концизнији него иначе, уједначенији, бржи. Момо Капор у Магији Београда сликовито помиње мазни, мелодични акценат. Та 'мазност' има своје лингвистичко објашњење: висок тон слога после узлазног акцента".

Ако постоји „београдски стил“ од кога он потиче - пита се Белић: да ли од Љубомира Ненадовића, Лазе Лазаревића, Војислава Илића или неког другог? Да ли су се они толико разликовали својим језиком од Бранка Радичевића или 
Змаја? Нема „београдског стила“ јединственог, Белићев је коначни став, он може бити само апстракција различитих београдских стилова произашао из слободе језичког стварања писаца и грађанског становништва, која уосталом припада сваком живом народном језику.

Заговорницима постојања „београдског стила“ добро су дошле дилеме Милке Ивић, које је поставила у књизи $O$ Вуковом и вуковском језику, а на које указује лист Данас: да ли село у 20. вијеку може бити узор говора и у граду, првенствено у Београду, „којег види као јединог легитимног творца књижевног језика у модерном добу“? Треба ли се ослободити заблуде да је „градски говор искварен и однарођен, а сеоски чист и узоран“, тражећи од новог књижевног језика, којег ће красити интелектуализованост, богатији рјечнички фонд, чија се синтакса неће учити од пастира и орача? - алудирајући на Вукове захтјеве које је поставио књижевницима. Андрић у тој Вуковој идеји не види ништа лоше - напротив, мишљења је да би „сто година било мало најбољем списатељу да сасвим научи језик орача и пастира“.

Да закључимо Белићевим мислима - „као што је својевремено учинио Вуков покрет тако и београдски и 'побеограђени' ствараоци уносе у књижевност, у књижевни језик свежину, нов живот, нове могућности, природан, неусиљен и слободан начин певања“. И језик Вука Караџића може данас послужити као један од стилова којим се са успехом служи и београдски књижевни језик, иако је одвојен од херојскоепске средине Вукова времена. Дакле, језик свих поменутих писаца, не искључујући ни Вука, основица је београдског језика. Има београдског језика, заснованог на Вуковој основици, али нема београдског стила - одговор је класика српске филологије Александра Белића. 


\title{
Miodrag Jovanović
}

\author{
ALEKSANDAR BELIĆ ABOUT VUK'S VIEWS \\ ON THE LANGUAGE OF THE AUTHORS OF HIS TIME \\ AS GUIDELINES FOR THE FORMATION OF THE \\ "BELGRADE CIRCLE"
}

\begin{abstract}
Summary
Aleksandar Belić was a great admirer of Vuk's personality and Vuk's work - he even wrote about it, most often with some enthusiasm. On the foundations of Vuk's reforms, in Belgrade at the end of the 19th and beginning of the 20th century a special poetic expression started to emerge, one which would more and more frequently be known as the Belgrade style, or even be considered the first literary language in Serbia. Whether this opinion was scientifically relevant - is something that Belić asked himself in more than one of his works. There was more than a little merit to his words: "There is a Belgrade language, based on Vuk's foundations, but there is no Belgrade style". In this paper we will attempt to reach a correct answer to this question.
\end{abstract}

Key words: Aleksandar Belić, Belgrade style, Vuk Karadžić, language. 